\title{
Rhenium-osmium geochronology of gersdorffite and skutterudite-pararammelsbergite links nickel-cobalt mineralization to the opening of the incipient Meliata Ocean (Western Carpathians, Slovakia)
}

\author{
Juraj Majzlan ${ }^{1}\left[\right.$ ] Tomáš Mikuš² $^{2}$ Stefan Kiefer ${ }^{1} \cdot$ Robert A. Creaser $^{3}$
}

Received: 11 May 2021 / Accepted: 16 February 2022 / Published online: 22 February 2022

(c) The Author(s) 2022

\begin{abstract}
The multi-orogenic crustal segment of the Central Western Carpathians comprises a Variscan basement that is host to small nickel-cobalt (Ni-Co) arsenide and sulfarsenide mineralizations at Lubietová-Kolba and Čierna Lehota (Slovakia). Here, we constrain the timing of Ni-Co mineralization by using rhenium-osmium (Re-Os) isotope geochemistry of (1) gersdorffite (NiAsS) after krutovite $\left(\mathrm{NiAs}_{2}\right)$ at Lubietová-Kolba, and (2) a mixture of skutterudite-pararammelsbergite $\left(\mathrm{CoAs}_{3}-\mathrm{NiAs}_{2}\right)$ from the Čierna Lehota deposit, hosted by metamorphosed carbonaceous rocks. Gersdorffite, which is bereft of common Os, returns a Re-Os model age of $238.2 \pm 1.0(2 \sigma)$ million years (Ma). Four aliquots of the skutterudite-pararammelsbergite mixture define a robust model 1 isochron at 238.2 $\pm 12.7(2 \sigma)$ Ma (mean square weighted deviates - MSDW $=0.95)$. A crustal source of Os, and by inference other metals, is inferred from the initial ${ }^{187} \mathrm{Os} /{ }^{188} \mathrm{Os}$ ratio of $0.90 \pm 0.01$ of this isochron. We conclude that studied $\mathrm{Ni}-\mathrm{Co}$ mineralizations are related to an extensional tectonic regime and hydrothermal fluid flow in connection with the opening of the Meliata ocean in the Middle Triassic (Ladinian).
\end{abstract}

Keywords Re-Os isotope geochemistry and geochronology $\cdot$ Arsenides $\cdot$ Western Carpathians

\section{Introduction}

Untangling the relationships between ore formation and tectono-metamorphic, magmatic-hydrothermal, or basinal-hydrothermal processes in polyphased crustal segments, such as the Western Carpathians, can be achieved by acquisition of accurate and precise geochronological data. Hydrothermal mineral deposits in the Western Carpathians formed in connection with tectonothermal events (Petrík 2000; Kohút 2004; Plašienka 2018) of Variscan (e.g.,

Editorial handling: N. Saintilan

Juraj Majzlan

Juraj.Majzlan@uni-jena.de

1 Institute of Geosciences, Friedrich-Schiller University, Burgweg 11, 07749 Jena, Germany

2 Earth Science Institute of the Slovak Academy of Sciences, Ďumbierska 1, Banská Bystrica, Slovakia

3 Department of Earth and Atmospheric Sciences, University of Alberta, Edmonton, AB T6G 2E3, Canada
Carboniferous, Majzlan et al. 2020) and Alpine ages (e.g., Cretaceous, Kohút et al. 2013). Yet, there is a long-standing controversy whether siderite-copper mineral deposits actually relate to mineralizing processes of Variscan or Alpine age in the Western Carpathians. For example, copper mineral deposits near Lubietová, including the Kolba $\mathrm{Cu}-\mathrm{Ni}-\mathrm{Co}$ occurrence, were considered to be syngenetic-stratiform of Variscan age, Variscan with Alpine remobilization, or epigenetic of Alpine age (Ilavský 1976; Varček 1978). Similar siderite-copper mineralization elsewhere in the Western Carpathians were proposed to be of Permian (Radvanec and Grecula 2016) or Cretaceous age (Hurai et al. 2002; Kiefer et al. 2020).

To resolve this ambiguity, absolute geochronology directly targeting minerals of economic interest (i.e., sulfides, sulfarsenides, or arsenides) is ideal. To this end, recent development of the ${ }^{187} \mathrm{Re}-{ }^{187} \mathrm{Os}$ chronometer has seen its application to sulfarsenides and arsenides (cobaltiteCoAsS, Saintilan et al. 2017; gersdorffite-NiAsS, Kiefer et al. 2020; rammelsbergite- $\mathrm{NiAs}_{2}$, Chernonozhkin et al. 2020). Herein, we investigate the mineralogy and timing 
of Ni-Co mineralization at two small historical deposits Lubietová-Kolba (Veporic Superunit) and Čierna Lehota (Tatric Superunit) in the Western Carpathians in central Slovakia. Nickel-cobalt sulfarsenides and arsenides dated by Re-Os geochronology in this work provide direct timing of the ore-forming events. Therefore, we were able to place the mineralizing processes in the greater context of the geodynamic evolution of the Western Carpathians in the Middle Triassic.

\section{Geological setting}

\section{Regional geology}

The Western Carpathians represent a segment of the AlpineCarpathian fold belt that formed as a result of subductioncollision in the Late Jurassic to Paleogene-Neogene within the mobile belt between the stable North European Platform and drifting continental fragments of Apulia/Adria (Plašienka 2018). The Western Carpathians are composed of (1) fragments of Early Paleozoic basement intruded by Variscan granitoids, (2) late Paleozoic to Mesozoic autochthonous sedimentary cover, and (3) Mesozoic, Paleogene, and Neogene sediments and volcanic rocks. The Central Western Carpathians (CWC) consist of the pre-Paleogene components grouped from north to south in three tectonic superunits: the Tatric sheet thrusted over the Veporic wedge, which is overlain by the Gemeric Superunit (Plašienka 2018). The Tatric and Veporic Superunits comprise large Devonian to Late Carboniferous syn- to post-collisional I- and S-type granitoids, Variscan felsic orthogneisses, paragneisses, migmatites, calc-silicate rocks, scarce metamorphosed black shales, and remnants of retrogressed meta-ultramafic rocks (Broska and Kubiš 2018; Kohút and Larionov 2021; Janák et al. 2020). Some Tatric complexes contain larger bodies of metamorphosed basalts, dolerites, gabbros, and sediments with variable amount of meta-organic matter and pyrite (Ivan and Méres 2015). These rocks are considered to represent metamorphosed and tectonically dismembered ophiolite sequences. Alpine metamorphic overprint was weak to negligible in the Tatric Superunit (Plašienka 2018) but significant in the Veporic Superunit (Jeřábek et al. 2012) where it reached the upper amphibolite facies.

\section{Ore geology}

The studied sites Lubietová-Kolba and Čierna Lehota were small historical deposits and the former adits and galleries are no longer accessible. The veins at the Lubietová-Kolba deposit are hosted by Variscan basement of the Veporic Superunit-biotite-quartz gneisses and amphibolites affected by retrograde Alpine metamorphism (Fig. 1). The veins are built by a system of lenses that strike NE-SW or N-S, dip steeply to the E, and reach a maximum thickness of several decimeters (Koděra et al. 1990). Pršek and Mikuš (2006) identified gersdorffite as the main mineral of the nickel-cobalt (Ni-Co) mineralization. A younger copper-bismuth $(\mathrm{Cu}-\mathrm{Bi})$ mineralization contains chalcopyrite, tennantite, and rare sulfosalts of the bismuthiniteaikinite series and kobellite.

Cobalt-nickel mineralization near Čierna Lehota is located in a SSW-NNE-striking lenses of metamorphosed carbonaceous pelitic and silicic rocks and amphibolites hosted by quartz-biotite paragneisses of the Tatric Superunit (Fig. 1). The graphitic rocks are interpreted to belong to the uppermost part of a dismembered ophiolitic sequence (Ivan and Méres 2015). The metamorphosed carbonaceous rocks contain pyrite-pyrrhotite horizons and crosscutting epigenetic $\mathrm{Ni}-\mathrm{Co}-\mathrm{Cu}-\mathrm{Bi}$ arsenide-sulfarsenide mineralization. In this study, we focus on this epigenetic $\mathrm{Ni}-\mathrm{Co}$ arsenide-sulfarsenide mineralization (Mikuš et al. 2013) and the younger $\mathrm{Cu}-\mathrm{Bi}$ mineralization with chalcopyrite, tennantite, hodrušite $\left(\mathrm{Cu}_{8} \mathrm{Bi}_{12} \mathrm{~S}_{22}\right)$, and kupčíkite $\left(\mathrm{Cu}_{3.4} \mathrm{Fe}_{0.6} \mathrm{Bi}_{5} \mathrm{~S}_{10}\right)$ (Pršek et al. 2005).

\section{Materials and methods}

\section{Materials}

Forty-six samples for this study were collected on dumps of the two small-scale mineral occurrences at LubietováKolba and Čierna Lehota. These samples were used for previous work on their mineralogy (Mikuš et al. 2013; Pršek and Mikuš 2006).

\section{Chemical analyses of ore minerals}

The major and minor element mineral chemistry of $\mathrm{Ni}-\mathrm{Co}$ arsenides and sulfarsenides was determined by wavelength-dispersive spectrometry (WDS) with an electron microprobe JEOL JXA 8530FE using the following analytical conditions: accelerating voltage $20 \mathrm{kV}$, probe current $15 \mathrm{nA}$, beam diameter 2-3 $\mu \mathrm{m}$, ZAF correction (Donovan et al. 1993), counting time $20 \mathrm{~s}$ on peak, $10 \mathrm{~s}$ on background (Earth Science Institute of the Slovak Academy of Sciences, Banská Bystrica). For WDS analyses, the following standards and X-ray lines were used: $\operatorname{Ag}(L \alpha)-\mathrm{Ag}$ metal, $\mathrm{S}(K \alpha)$-pyrite, $\mathrm{Cu}(K \alpha)$ and $\mathrm{Fe}(K \alpha)$-chalcopyrite, $\operatorname{As}(L \alpha)$-GaAs, $\mathrm{Sb}(L \alpha)$-stibnite, $\mathrm{Bi}(L \alpha)-\mathrm{Bi}_{2} \mathrm{~S}_{3}, \mathrm{Ni}(K \alpha)$ gersdorffite, $\operatorname{Co}(K \alpha)-\mathrm{Co}$ metal. 


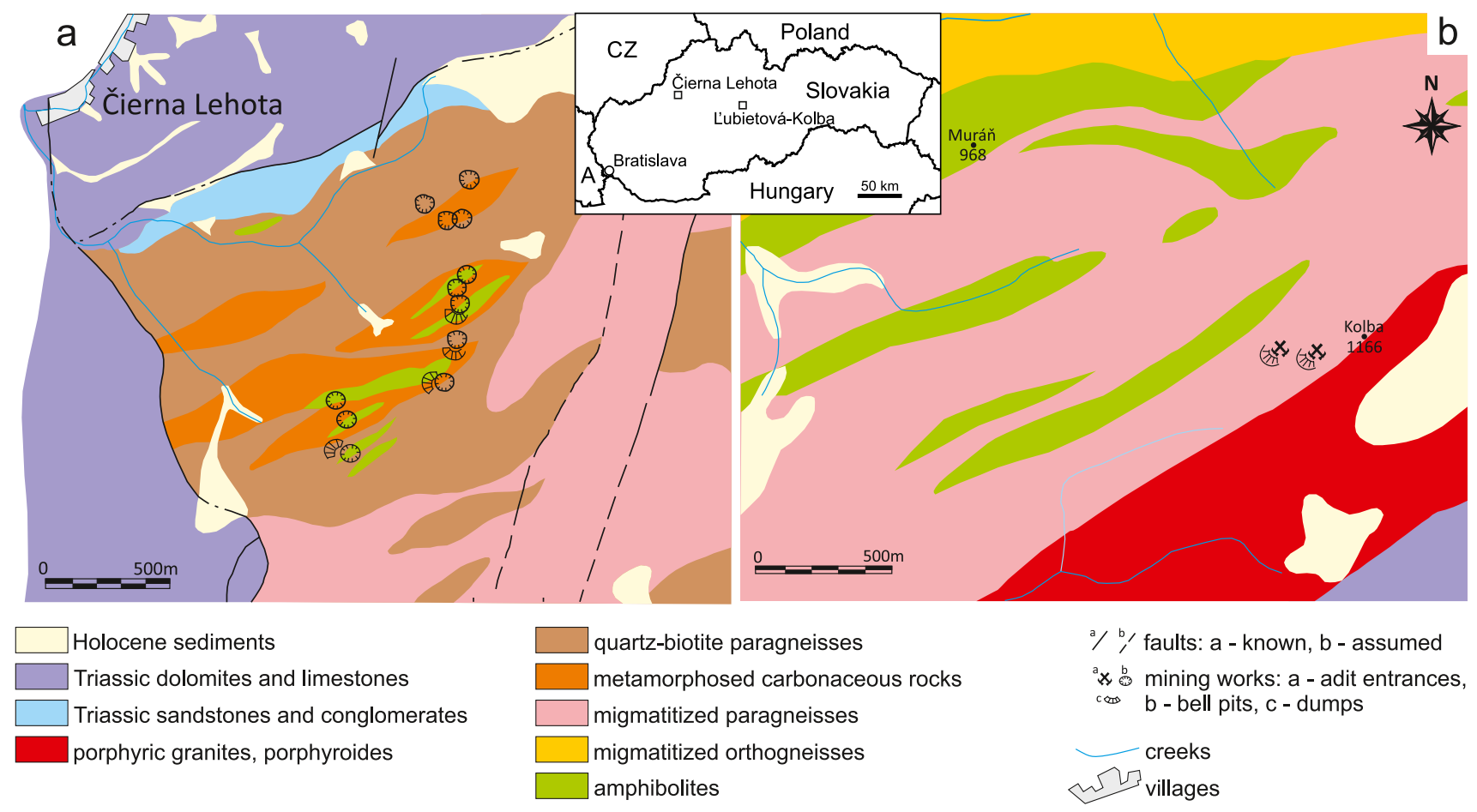

Fig. 1 Geological maps of the small deposits a) Čierna Lehota (with GPS coordinates $48.854485^{\circ} \mathrm{N}, 18.354002^{\circ} \mathrm{E}$ ) and Lubietová-Kolba $\left(48.748513^{\circ} \mathrm{N}, 19.445786^{\circ} \mathrm{E}\right)$, simplified after Hraško (2021) and

\section{Production and characterization of mineral separates}

A subset of four samples from Lubietová-Kolba and ten samples from Čierna Lehota, which were extensively studied by means of reflected-light microscopy and electron microprobe analyses, were selected for the separation of arsenide/sulfarsenide minerals. The samples were crushed to fragment size of $\approx 0.5 \mathrm{~cm}$ and examined under binocular microscope. Fragments of massive mineralization were taken for further size reduction in an agate mortar and pestle to particle sizes between 1 and $2 \mathrm{~mm}$. Fragments that were deemed to only contain $\mathrm{Ni}-\mathrm{Co}$ arsenides and sulfarsenides and no younger chalcopyrite or Bi-sulfosalts were hand-picked under binocular microscope. For each sample, a total of $1 \mathrm{~g}$ of material was collected, i.e., either gersdorffite-only mineral separate or mixture of skutterudite-pararammelsbergite.

Before undertaking full Re-Os isotope geochemistry procedures, each mineral separate was characterized by powder $\mathrm{X}$-ray diffraction to document the purity of this separate. Then, ca. 20-mg aliquots of each mineral separate were analyzed for their Re contents to determine the ideal sample weight to be digested with an adequate volume of "Re + Os" in the full protocols.

For each Re-Os analysis, between 90 and $125 \mathrm{mg}$ of gersdorffite (Kolba) and a mixture of pararammelsbergite
Polák (2003), respectively. The inset shows the position of the two deposits in central Europe

and skutterudite (Čierna Lehota) were weighed into thickwalled borosilicate Carius tubes (Shirey and Walker 1995) then dissolved in inverse Aqua Regia $(2 \mathrm{~mL}$ of $10 \mathrm{~N} \mathrm{HCl}$ and $6 \mathrm{~mL} 16 \mathrm{~N} \mathrm{HNO}_{3}$ ) at $220{ }^{\circ} \mathrm{C}$ for $48 \mathrm{~h}$ at the Crustal Re-Os Geochronology Laboratory, University of Alberta, Edmonton, Canada. An initial Re-Os analysis using a ${ }^{185} \mathrm{Re}+{ }^{190} \mathrm{Os}$ spike showed little common Os in sample KO-4, with ${ }^{187}$ Os* comprising $>99.6 \%$ of the Os measured. As such, for this sample, a mixed double-Os spike $\left({ }^{185} \mathrm{Re}+{ }^{190} \mathrm{Os}+{ }^{188} \mathrm{Os}\right)$ was then used (Markey et al. 2007). For the CL samples, initial analyses revealed high levels of common Os and low Re/ Os ratios. The laboratory protocol used here is described in full by Morelli et al. (2010) and Hnatyshin et al. (2020). In brief, Os was isolated and purified from the inverse aqua regia solution by chloroform $\left(\mathrm{CHCl}_{3}\right)$ solvent extraction, hydrobromic acid reduction, and microdistillation. The Re was isolated using $\mathrm{HCl}-\mathrm{HNO}_{3}$-based anion exchange chromatography. The Re and Os isotopic compositions were determined by negative thermal ionization mass spectrometry using a Thermo Scientific Triton mass spectrometer at the University of Alberta. Rhenium and Os were loaded onto $\mathrm{Ni}$ and $\mathrm{Pt}$ filaments, respectively. Rhenium was measured as $\mathrm{ReO}_{4}^{-}$in static mode on Faraday collectors, whereas Os was measured as $\mathrm{OsO}_{3}{ }^{-}$in peak-hopping mode on a single electron multiplier (Creaser et al. 1991; Völkening et al. 1991). Measurement quality was monitored by measurements of 
in-house Re and Os standards over the analysis period $\left({ }^{1}\right.$ ${ }^{85} \mathrm{Re} /{ }^{187} \mathrm{Re}=0.59775 \pm 0.00042, n=8 ; \mathrm{AB}-2$ Os Standard, $\left.{ }^{187} \mathrm{Os} /{ }^{188} \mathrm{Os}=0.10689 \pm 0.000611 \mathrm{SD}, n=14\right)$ ). A total procedural blank of $1.62 \mathrm{pg} \mathrm{Re}$ and $59 \mathrm{fg}$ Os with a blank ${ }^{187} \mathrm{Os} /{ }^{188} \mathrm{Os}$ ratio of 0.26 was measured at the time of analysis. The Reference Material 8599 Henderson molybdenite (Markey et al. 2007) is routinely analyzed as an age standard with the mixed double-Os spike, and during the past 6 years returned an average Re-Os date of $27.78 \pm 0.07 \mathrm{Ma}$ $(n=26)$, indistinguishable from the reference age value of $27.7 \pm 0.1 \mathrm{Ma}$ (Wise and Watters 2011). The ${ }^{187} \mathrm{Re}$ decay constant used is $1.666 \times 10^{-11} \pm 5.165 \times 10^{-14} \mathrm{a}^{-1}$ (Smoliar et al. 1996). The analytical uncertainties quoted result from full error propagation of mass spectrometer analyses, blanks, and long-term uncertainties in standard Re and Os.

\section{Results}

\section{Ore mineralization at Kolba}

The Ni-Co mineralization at Kolba is confined to veinlets (up to $10 \mathrm{~cm}$ thick) in the host metamorphic rocks. The paragenetic sequence, as determined from observation of hand specimens, polished sections in polarized-light microscopy, and electron microprobe, is shown in Fig. 2. The oldest minerals are massive albite and carbonates. Carbonates are sparse, dispersed in the albite mass, dominated by dolomite with average $\mathrm{Fe} /(\mathrm{Fe}+\mathrm{Mg}$ ) molar ratio of 0.19 (analyses 1-8, ESM Table 1). Magnesium-Fe carbonates with $\mathrm{Fe} /(\mathrm{Fe}+\mathrm{Mg})$ molar ratio of 0.39 are less common (analyses 9-12, ESM Table 1). The predominant mineral among the $\mathrm{Ni}-\mathrm{Co}-\mathrm{Fe}$ sulfarsenides is gersdorffite, but its composition is variable (analyses 24-149, ESM Table 2), with diffuse, oscillatory, and sector zoning observed (Fig. 3a, b, ESM Fig. 1). Gersdorffite commonly shows cores enriched in As and rims bearing more S (Fig. 3a). Locally, cores may attain the composition of diarsenides (Fig. 3b, analyses 13-23 ESM Table 2), e.g., $\left(\mathrm{Ni}_{0.95} \mathrm{Co}_{0.02} \mathrm{Fe}_{0.02}\right)\left(\mathrm{As}_{1.68} \mathrm{~S}_{0.33}\right)$ in the parts the richest in As (analysis 16, ESM Table 2). Based on optical (isotropy, reflectance higher than that of gersdorffite) and chemical composition, these diarsenides are identified as krutovite. The contacts between krutovite and gersdorffite show diffuse, gradual change in the chemical composition (Fig. 3b). Gersdorffite is replaced along fractures and rims of the crystals by $\mathrm{Cu}-\mathrm{Bi}$ minerals, chalcopyrite, tennantite, or Bi sulfosalts (Fig. 3c).

In light of its standard paragenetic association, a mineral composition matching the main mineralization type described here, and its high Re content $\left(264 \mathrm{ng} \mathrm{g}^{-1}\right)$, sample KO-4, was selected for Re-Os dating. The mineral separate used for the Re-Os geochronology consists of single-phase gersdorffite as confirmed by powder X-ray diffraction.

\section{Ore mineralization at Čierna Lehota}

The ore mineralization at Čierna Lehota is hosted by metamorphosed carbonaceous rocks and the paragenetic sequence there is shown in Fig. 2. It consists of syngenetic mineralization, dominated by massive aggregates and impregnations of pyrrhotite and pyrite and epigenetic $\mathrm{Ni}-\mathrm{Co}-\mathrm{As}-\mathrm{Cu}-\mathrm{Bi}$ mineralization.

The epigenetic Ni-Co-As ores considered here have spheroid, concentric, or collomorph textures (Fig. 3d-f,
Fig. 2 Paragenetic sequences for the mineralizations from Čierna Lehota (right) and Lubietová-Kolba (left)

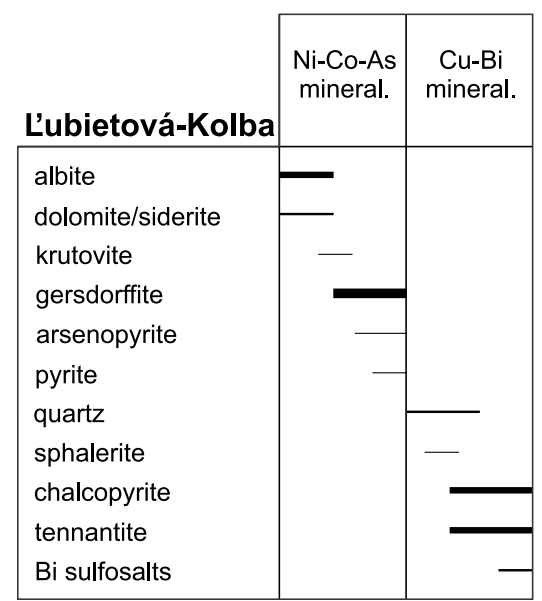

\begin{tabular}{|l|l|l|l|}
\cline { 2 - 3 } \multicolumn{1}{l|}{} & $\begin{array}{c}\text { syngenetic } \\
\text { mineral. }\end{array}$ & $\begin{array}{c}\text { Ni-Co-As } \\
\text { mineral. }\end{array}$ & $\begin{array}{c}\text { Cu-Bi } \\
\text { mineral. }\end{array}$ \\
\hline $\begin{array}{l}\text { pyrite } \\
\text { pyrrhotite } \\
\text { sphalerite } \\
\text { galena } \\
\text { chalcopyrite }\end{array}$ & & & \\
quartz & & & \\
siderite & & & \\
Co skutterudite & & & \\
Ni-Fe skutterudite & & & \\
pararammelsbergite & & & \\
Ni-löllingite & & & \\
bismuth & & & \\
löllingite & & & \\
arsenopyrite & & & \\
gersdorffite & & & \\
tennantite & & & \\
Bi sulfosalts & & & \\
\hline
\end{tabular}



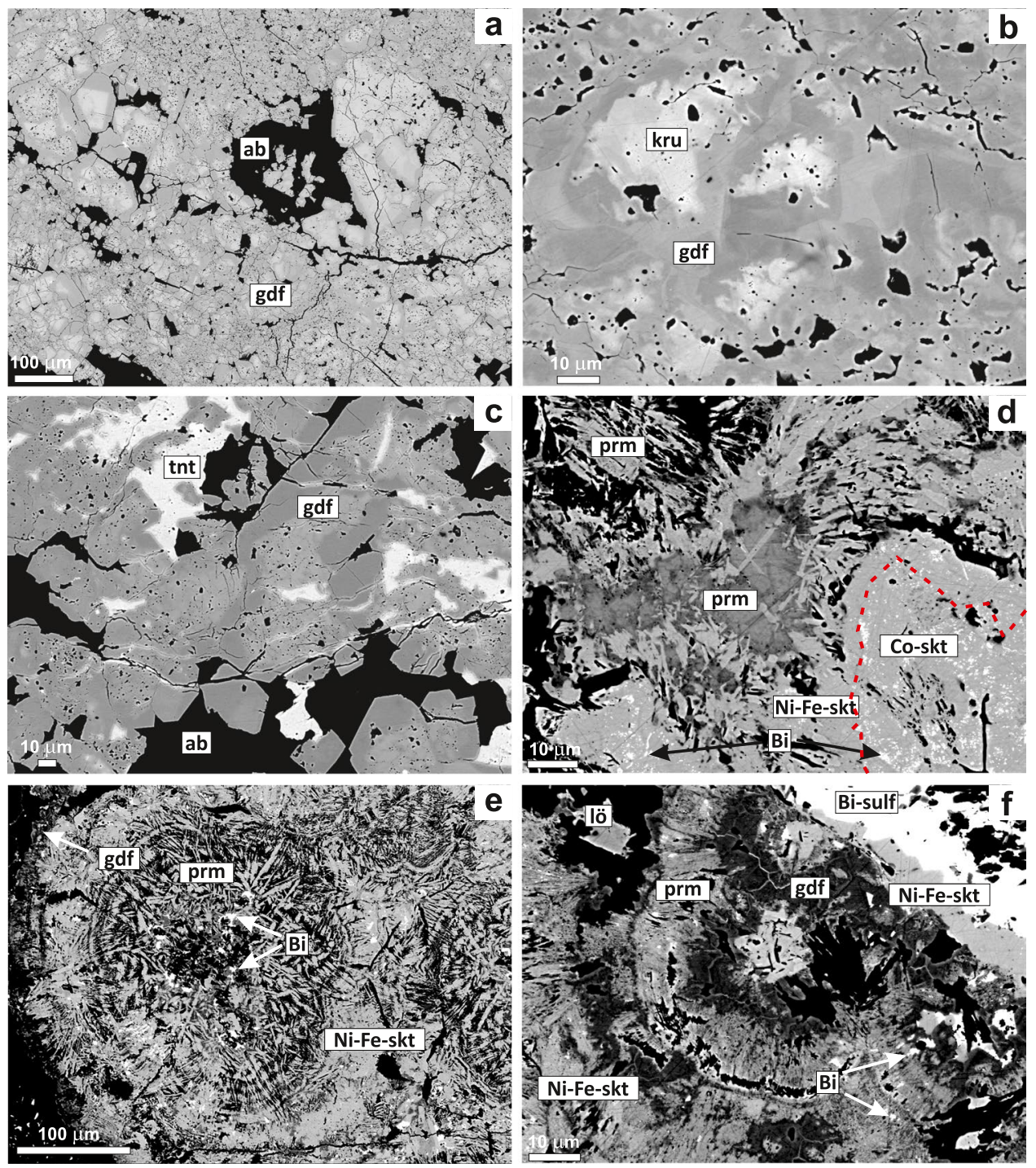

Fig. 3 Back-scattered electron (BSE) images of arsenides and sulfarsenides from Kolba $(\mathbf{a}-\mathbf{c})$ and Čierna Lehota (d-f). a Zoned aggregates of gersdorffite. The light gray cores are enriched in $\mathrm{Ni}$, As; the darker grey rims are richer in Fe (EMP analyses 103-124 in Table S2). Sample KL-10. b Anhedral, early krutovite enclosed in gersdorffite (an. 13-17 and 66-82 in ESM Table 2). Sample K-1. c Gersdorffite with cores enriched in $\mathrm{Ni}$ and $\mathrm{As}$ and rims enriched in Fe (an. 83-99 in ESM Table 2) replaced by younger tennantite. Sample K-4. d Earlier Co skutterudite with numerous minute bismuth inclusions is overgrown by $\mathrm{Ni}-\mathrm{Fe}$ skutterudite (an. 150-188 in ESM Table 3). The contact between the two skutterudite types is highlighted in one of the aggregates by the dashed red line. Skutterudite

ESM Figs. 2, 3) and consist of fine-grained intergrowths of early skutterudite $\left[(\mathrm{Co}, \mathrm{Ni}, \mathrm{Fe}) \mathrm{As}_{3}\right]$ and pararammelsbergite $\left(\mathrm{NiAs}_{2}\right)$, occasionally with inclusions of native bismuth (Fig. 3d, ESM Fig. 2). Skutterudite is Co-rich (analyses 150, ESM Table 3), whereas pararammelsbergite is chemically near the composition $\mathrm{NiAs}_{2}$, with little Fe (average $1.9 \mathrm{wt} \%$ ), $\mathrm{S}$ (3.7 wt\%), and no Co (analyses 197-225, ESM Table 3). associates with pararammelsbergite. Sample CL-1. e Spheroid, concentric aggregates of early pararammelsbergite, overgrown by $\mathrm{Ni}-\mathrm{Fe}$ skutterudite, with tiny bismuth inclusions in the center of the aggregate. Sample CL-1. f Spheroid aggregate of pararammelsbergite and $\mathrm{Ni}-\mathrm{Fe}-$ bearing skutterudite is replaced by gersdorffite. The subhedral löllingite crystal belongs also the latest minerals of the $\mathrm{Ni}-\mathrm{Co}-\mathrm{As}$ mineralization. The minute bismuth inclusions and $\mathrm{Bi}$ sulfosalts fill fractures in the aggregates of the $\mathrm{Ni}-\mathrm{Co}-\mathrm{As}$ minerals. Mineral abbreviations: Skt, skutterudite; prm, pararammelsbergite; gdf, gersdorffite; ab, albite; Bi-sulf, Bi sulfosalts; lö, löllingite; tnt, tennantite; kru, krutovite

The abundant aggregates of Co-rich skutterudite and pararammelsbergite are overgrown by later skutterudite that is essentially devoid of Co (Fig. 3d, e, analyses 151-188, ESM Table 3) and by later pararammelsbergite. Texturally, the two skutterudite types are difficult to distinguish because both are part of spheroid, concentric, and porous aggregates. Those discrete skutterudite 
types can only be distinguished from one another by their Co content. The later skutterudite contains fewer or no bismuth inclusions (Fig. 3d) but may contain inclusions of löllingite with distinctly elevated $\mathrm{Ni}$ content (up to $7.7 \mathrm{wt} \% \mathrm{Ni}$, analyses 189-191, ESM Table 3). The later, darker gray pararammelsbergite in back-scattered electron images contains less As and more $\mathrm{S}$ than the early pararammelsbergite (analyses 197-225, ESM Table 3, Fig. 3d). The Ni-Co-As mineralization terminated with the crystallization of much less abundant, small (up to $20 \mu \mathrm{m}$ ) euhedral crystals of pararammelsbergite (with $\mathrm{S}$ concentration up to $12 \mathrm{wt} \%$ ), skutterudite, löllingite, arsenopyrite, and gersdorffite (Fig. 3f, analyses 192-196 and 226-235, ESM Table 3). The $\mathrm{Ni}-\mathrm{Co}-\mathrm{As}$ minerals are crushed, healed, and replaced by native bismuth, tennantite, and a variety of bismuth sulfosalts (Fig. 3f).

In light of their predominance, Re-Os dating was carried out on mixtures dominated by skutterudite and pararammelsbergite. Powder X-ray diffraction measurement showed that the separates contain mostly these two minerals, but also minor gersdorffite and arsenopyrite. Owing to the fine-grained nature of the arsenides and sulfarsenides, it is impossible to separate the individual minerals from each other.

\section{Re-Os geochronology of the Ni-Co sulfarsenides}

The result of the Re-Os age determination for Kolba gersdorffite sample KO-4 is a model age of $238.2 \pm 1.0 \mathrm{Ma}$ using the mixed double-Os spike (Table 1). Samples of skutterudite-pararammelsbergite from Čierna Lehota show low Re/Os ratios (4.2-7.7) and high Os contents (320-390 ppt). The ${ }^{187} \mathrm{Re} /{ }^{188}$ Os ratios (22.5-41.9) are positively correlated with highly radiogenic ${ }^{187} \mathrm{Os} /{ }^{188} \mathrm{Os}$ ratios (0.99-1.07), yielding a 4-point model 1 isochron regression (mean square weighted deviates, MSWD $=0.95$ ) with a date of $238.2 \pm 12.7 \mathrm{Ma}(2 \sigma)$ and an initial ${ }^{187} \mathrm{Os} /{ }^{188} \mathrm{Os}$ ratio of $0.90 \pm 0.01$ (Table 2, Fig. 4).

\section{Discussion}

\section{Timing and source of metals in Ni-Co-As mineralization}

At Čierna Lehota, there is no evidence of intramineralization tectonics or cross-cutting relationships among the various arsenides and sulfarsenides. We interpret that the $\mathrm{Ni}-\mathrm{Co}-\mathrm{As}$ mineralization formed in a single hydrothermal pulse, and the mineralizing fluids evolved from an early Corich and S-poor one yielding $\mathrm{Co}-\mathrm{Ni}-\mathrm{As}$ minerals to fluids poorer in metals but enriched in $\mathrm{S}$ late in the mineralizing sequence. Such evolution is characteristic for the so-called five-element association (Scharrer et al. 2019) in which the triarsenides are commonly Co-dominated. At Čierna Lehota, the presence of skutterudite is a testament of highly reducing conditions, logically ensured by the host metamorphosed carbonaceous rocks. The spheroid, concentric, and collomorph textures attest to rapid precipitation of the arsenides during influx of the fluids into these rocks. Therefore, the $\mathrm{Re}-\mathrm{Os}$ isochron from mineral separates consisting of skutterudite-pararammelsbergite from Čierna Lehota most likely correctly dates mineralization at ca. $238 \mathrm{Ma}$. This interpretation is further supported by the Re-Os model age of gersdorffite at Kolba.

The age of the metamorphosed carbonaceous rocks in Čierna Lehota is known only as Early Paleozoic (Ivan and Méres 2015), but it is reasonable to expect that such rocks will have elevated ${ }^{187} \mathrm{Os} /{ }^{188} \mathrm{Os}$ ratios at the time of mineralization, given up to $300 \mathrm{Myr}$ of growth in radiogenic ${ }^{187} \mathrm{Os}$ after deposition of the black shale precursors. The initial ${ }^{187} \mathrm{Os} /{ }^{188} \mathrm{Os}$ of $0.90 \pm 0.01$ points to interaction of the fluids with crustal lithologies, such as the metabasic and metamorphosed carbonaceous rocks as a source of Os, and possible leaching of the elements in the Ni-Co mineralizations from these rocks. The metabasic rocks contain on average 152 ppm Ni and 46 ppm Co (Ivan and Méres 2015). The metamorphosed carbonaceous rocks have much lesser $\mathrm{Ni}$ (5 ppm) and Co $(0.8 \mathrm{ppm})$ contents. Hence, the assumed source of $\mathrm{Ni}$ and $\mathrm{Co}$ are the metabasic rocks.

Table 1 Re-Os isotopic data and model age for gersdorffite from sample KO-4 (Lubietová-Kolba) using a mixed double-Os ${ }^{185} \mathrm{Re}+{ }^{188} \mathrm{Os}+{ }^{190}$ Os spike

\begin{tabular}{|c|c|c|c|c|c|c|c|c|c|c|}
\hline \multirow[t]{2}{*}{ Sample } & Weight & $\operatorname{Re}$ & $\pm 2 \sigma$ & ${ }^{187} \mathrm{Re}$ & $\pm 2 \sigma$ & ${ }^{187} \mathrm{Os}$ & $\pm 2 \sigma$ & $\begin{array}{l}\text { Total common } \\
\text { Os }^{\mathrm{a}}\end{array}$ & Model age & $\pm 2 \sigma^{\mathrm{b}}$ \\
\hline & $\mathrm{mg}$ & $\mathrm{ppb}$ & & $\mathrm{ppb}$ & & $\mathrm{ppb}$ & & pg & $\mathrm{Ma}$ & \\
\hline KO-4 & 112 & 264.0 & 0.7 & 165.9 & 0.4 & 0.6597 & 0.0010 & 4.6 & 238.2 & 1.0 \\
\hline
\end{tabular}

${ }^{\mathrm{a}}$ Total common Os includes analytical blank of $0.059 \mathrm{pg}$ Os

${ }^{\mathrm{b}}$ Age uncertainty includes uncertainty in ${ }^{187} \mathrm{Re}$ decay constant

$m g$ milligrams, $p p b$ parts per billion, $M a$ millions of years before present, $p g$ picograms 


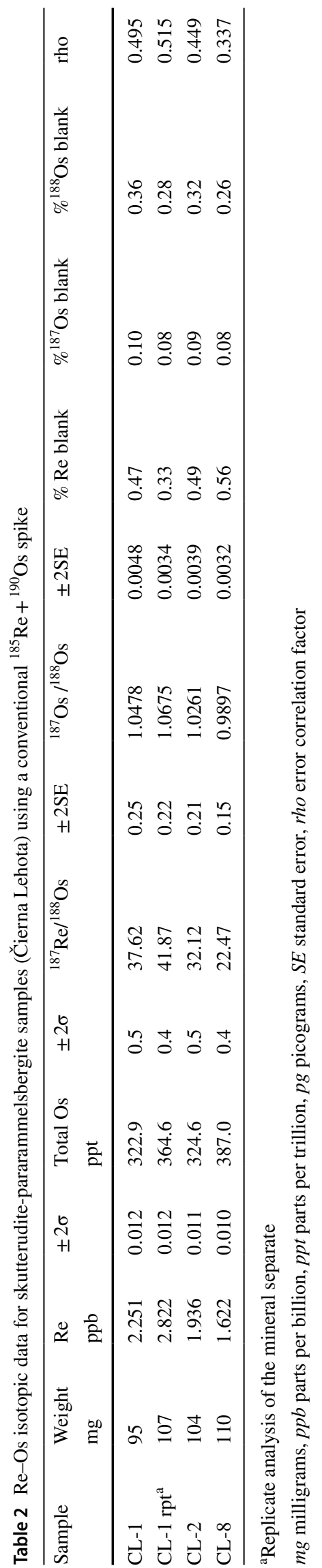

\section{Link of the investigated mineralizations to the tectonic evolution of Western Carpathians}

During the Triassic, the Tatric and Veporic superunits of the Western Carpathians experienced a period of relative tectonic and magmatic quiescence between the main Variscan phase of igneous and tectonometamorphic activity (Late Devonian-Mississippian; Petrík et al. 2020; Kohút and Larionov 2021) and the main Alpine phase of thrusting and metamorphism (Cretaceous; Plašienka 2018). An extensional setting in Middle-Late Triassic (Plašienka 2018) related to the incipient stage of the opening of the Meliata ocean is documented in the magmatic (Putiš et al. 2019) and sedimentary record in the study area (Gawlick and Missoni 2015; Plašienka et al. 2019). Such an extensional regime could have opened pathways for fluid circulation and perhaps also fueled short-lasting and small, localized heat pulses of igneous activity. Metals were extracted by the circulating fluids locally, from crustal sources (see discussion above), as indicated by the initial ${ }^{187} \mathrm{Os} /{ }^{188} \mathrm{Os}$ ratio for the samples from Čierna Lehota. Triassic model $\mathrm{Pb}-\mathrm{Pb}$ ages from several small barite-galena occurrences in the Western Carpathians (Chernyshev et al. 1984) suggest that the conditions of extensional tectonics related to the opening of the Meliata ocean may have created a number of small hydrothermal deposits, not only those investigated in this work. Therefore, additional work combining geology applied to mineral deposits and highprecision Re-Os geochronology of sulfides and sulfarsenides is warranted to decipher further the long-lived history of hydrothermal events in the Western Carpathians.

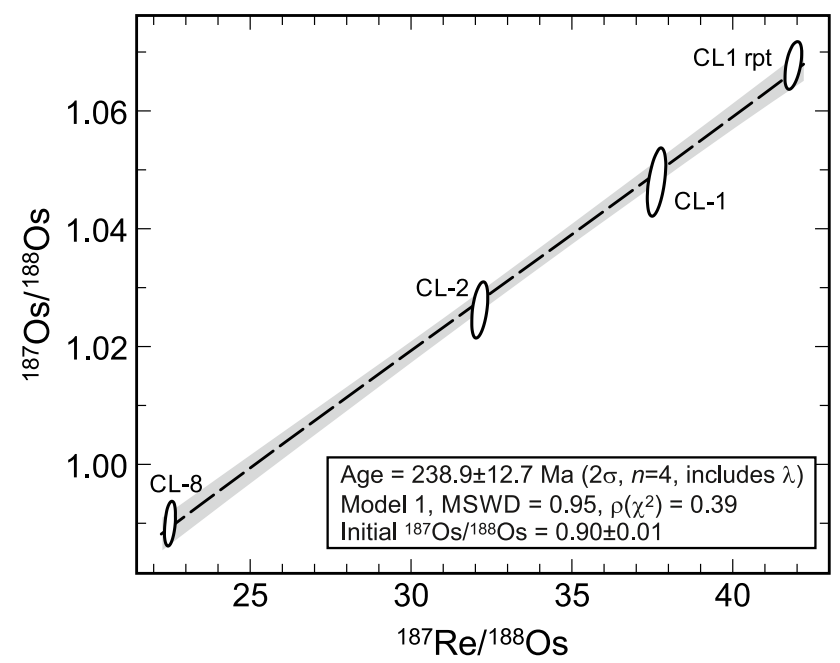

Fig. 4 Re-Os isochron diagram for skutterudite-pararammelsbergite analyses from Čierna Lehota using IsoplotR (Vermeesch 2018). Age uncertainty includes uncertainty in the ${ }^{187} \mathrm{Re}$ decay constant (Smoliar et al. 1996) 
Supplementary Information The online version contains supplementary material available at https://doi.org/10.1007/s00126-022-01101-7.

Acknowledgements We appreciate the comments of the two anonymous reviewers as well as those by the associate editor and chief editor that improved the manuscript. We are thankful to L. Ackerman and J. Durišová (at Czech Academy of Sciences in Prague) for the preliminary Re analyses of the mineral separates.

Funding Open Access funding enabled and organized by Projekt DEAL. This work was financially supported by a Deutsche Forschungsgemeinschaft grant KI 2131/2-1 and the Slovak VEGA agency, grant $0028 / 20$

Data availability The supporting electronic information contains: Electron-microprobe analyses of carbonates, arsenides/sulfarsenides from Lubietová-Kolba and Čierna Lehota (XLSX).

\section{Declarations}

Conflict of interest The authors declare no competing interests.

Open Access This article is licensed under a Creative Commons Attribution 4.0 International License, which permits use, sharing, adaptation, distribution and reproduction in any medium or format, as long as you give appropriate credit to the original author(s) and the source, provide a link to the Creative Commons licence, and indicate if changes were made. The images or other third party material in this article are included in the article's Creative Commons licence, unless indicated otherwise in a credit line to the material. If material is not included in the article's Creative Commons licence and your intended use is not permitted by statutory regulation or exceeds the permitted use, you will need to obtain permission directly from the copyright holder. To view a copy of this licence, visit http://creativecommons.org/licenses/by/4.0/.

\section{References}

Broska I, Kubiš M (2018) Accessory minerals and evolution of tinbearing S-type granites in the western segment of the Gemeric Unit (W. Carpathians). Geol Carpath 69:483-497

Chernonozhkin SM, Mercadier J, Reisberg L, Luais B, Zimmermann C, Morlot C, Salsi L, Lecomte A, Rouer O, Brouand M, Doney A, Ledru P (2020) Evaluation of rammelsbergite $\left(\mathrm{NiAs}_{2}\right)$ as a novel mineral for ${ }^{187} \mathrm{Re}^{187} \mathrm{Os}$ dating and implications for unconformityrelated U deposits. Geochim Cosmochim Acta 280:85-10

Chernyshev I, Cambel B, Koděra M (1984) Lead isotopes in galenas of the West Carpathians. Geol Carpath 35:307-327

Creaser RA, Papanastassiou DA, Wasserburg GJ (1991) Negative thermal ion mass spectrometry of osmium, rhenium, and iridium. Geochim Cosmochim Acta 55:397-401

Donovan JJ, Snyder DA, Rivers ML (1993) An improved interference correction for trace element analysis. Microbeam Anal 2:23-28

Gawlick H-J, Missoni S (2015) Middle Triassic radiolarite pebbles in the Middle Jurassic Hallstatt Mélange of the Eastern Alps: implications for Triassic-Jurassic geodynamic and paleogeographic reconstructions of the western Tethyan realm. Facies 61:13

Hnatyshin D, Creaser RA, Meffre S, Stern RA, Wilkinson JJ, Turner EC (2020) Understanding the microscale spatial distribution and mineralogical residency of Re in pyrite: examples from carbonatehosted $\mathrm{Zn}-\mathrm{Pb}$ ores and implications for pyrite Re-Os geochronology. Chem Geol 533:119427
Hraško L (ed) (2021) Geological map of the Strážovské vrchy Mts. (Eastern Part). 1:50 000. MŽP SR - ŠGÚDŠ, Bratislava

Hurai V, Harčová E, Huraiová M, Ozdín D, Prochaska W, Wiegerová V (2002) Origin of siderite veins in the Western Carpathians I. $\mathrm{P}-\mathrm{T}-\mathrm{X}-\delta^{13} \mathrm{C}-\delta^{18} \mathrm{O}$ relations in ore-forming brines of the Rudñany deposits. Ore Geol Rev 21:67-101

Ilavský J (1976) An stratigraphische Hiate gebundene Vererzungen in den Tschechoslowakischen Karpaten. Miner Deposita 11:93-110

Ivan P, Méres Š (2015) Geochemistry of amphibolites and related graphitic gneisses from the Suchý and Malá Magura Mountains (central Western Carpathians) - evidence for relics of the Variscan ophiolite complex. Geol Carpath 66:347-360

Janák M, Méres Š, Medaris LG Jr (2020) Eclogite facies metaultramafite from the Veporic Unit (Western Carpathians, Slovakia). Geol Carpath 71:209-220

Jeřábek P, Lexa O, Schulmann K, Plašienka D (2012) Inverse ductile thinning via lower crustal flow and fold-induced doming in the West Carpathian Eo-Alpine collisional wedge. Tectonics 31:TC5002

Kiefer S, Števko M, Ozdín D, Gerdes A, Creaser RA, Szczerba M, Majzlan J (2020) Geochronological and geochemical constraints on the carbonate-sulfarsenide veins in Dobšiná, Slovakia: U/Pb ages of hydrothermal carbonates, Re/Os age of gersdorffite, and K/Ar ages of fuchsite. J Geosci 65:229-247

Koděra M (ed) (1990) Topographic mineralogy of Slovakia. Second Part. Veda (in Slovak)

Kohút M (2004) The orthogneisses of the Western Carpathians: an overview. Mineral Slov 36:141-155 (in Slovak)

Kohút M, Larionov AN (2021) From subduction to collision: genesis of the Variscan granitic rocks from the Tatric Superunit (W. Carpathians, Slovakia). Geol Carpath 72:96-113

Kohút M, Stein H, Uher P, Zimmerman A, Hraško L' (2013) Re-Os and $\mathrm{U}-\mathrm{Th}-\mathrm{Pb}$ dating of the Rochovce granite and its mineralization (Western Carpathians, Slovakia). Geol Carpath 64:71-79

Láznička P (1966) Cobaltite at the deposit Kolba eastward from Lubietová. Čas Mineral Geol 11:177-180 (in Czech)

Majzlan J, Chovan M, Hurai V, Luptáková J (2020) Hydrothermal mineralisation of the Tatric Superunit (Western Carpathians, Slovakia): I. a review of mineralogical, thermometry and isotope data. Geol Carpath 71:85-112

Markey R, Stein HJ, Hannah JL, Zimmerman A, Selby D, Creaser RA (2007) Standardizing Re-Os geochronology: a new molybdenite reference material (Henderson, USA) and the stoichiometry of Os salts. Chem Geol 244:74-87

Mikuš T, Chovan M, Ponomarenko O, Bondarenko S, Grinchenko O (2013) Hydrothermal nickel mineralization from the black shales in Čierna Lehota (Western Carpathians, Slovakia). Miner J (Ukraine) 35:27-32

Morelli RM, Bell CC, Creaser RA, Simonetti A (2010) Constraints on the genesis of gold mineralization at the Homestake Gold Deposit, Black Hills, South Dakota from rhenium-osmium sulfide geochronology. Miner Deposita 45:461-480

Petrík I (2000) Multiple sources of the Western Carpathian Variscan granitoids: a review of $\mathrm{Rb} / \mathrm{Sr}$ and $\mathrm{Sm} / \mathrm{Nd}$ data. Geol Carpath 51:145-158

Petrík I, Broska I, Uher P (1994) Evolution of the Western Carpathian granite magmatism: age, source rock, geotectonic setting and relation to the Variscan structure. Geol Carpath 45:283-291

Petrík I, Janák M, Vaculovič T, Konečný P, Méres Š (2020) Variscan high-pressure metamorphism of kyanite-bearing paragneisses hosting eclogites in the Veporic unit, W. Carpathians: Evidence from $\mathrm{Th}-\mathrm{U}-\mathrm{Pb}$ dating of monazite. Geol Carpath 71:485-502

Plašienka D (2018) Continuity and episodicity in the early Alpine tectonic evolution of the Western Carpathians: how large-scale processes are expressed by the orogenic architecture and rock record data. Tectonics 37:2029-2079

Plašienka D, Méres Š, Ivan P, Sýkora M, Soták J, Lačný A, Aubrecht R, Bellová S, Potočný T (2019) Meliatic blueschists and their detritus 
in Cretaceous sediments: new data constraining tectonic evolution of the West Carpathians. Swiss J Geosci 112:55-81

Polák M (ed) (2003) Geological map of the Starohorské vrchy Mts, Čierłaž and Northern part of Zvolen basin 1:50 000. MŽP SR ŠGÚDŠ, Bratislava

Pršek J, Mikuš T (2006) Bi sulfosalts from the locality L'ubietováKolba. Mineral Slov 38:159-164 (in Slovak)

Pršek J, Mikuš T, Makovicky E, Chovan M (2005) Cuprobismutite, kupčíkite, hodrushite and associated sulfosalts from the black shale hosted Ni-Bi-As mineralization at Čierna Lehota, Slovakia. Eur J Mineral 17:155-162

Putiš M, Li J, Ružička P, Ling X, Nemec O (2016) U/Pb SIMS zircon dating of a rhyolite intercalation in Permian siliciclastics as well as a rhyodacite dyke in micaschists (Infratatricum, W. Carpathians). Mineral Slov 48:99-108

Putiš M, Soták J, Li Q-L, Ondrejka M, Li X-H, Hu Z, Ling X, Nemec O, Németh Z, Ružička P (2019) Origin and age determination of the Neotethys Meliata basin ophiolite fragments in the late Jurassic-Early Cretaceous accretionary wedge mélange (Inner Western Carpathians, Slovakia). Minerals 9:652

Radvanec M, Grecula P (2016) Geotectonic and metallogenetic evolution of Gemericum (inner Western Carpathians) from Ordovician to Jurassic. Mineral Slov 48:105-118

Saintilan NJ, Creaser RA, Bookstrom AA (2017) Re-Os systematics and geochemistry of cobaltite (CoAsS) in the Idaho cobalt belt, Belt-Purcell Basin, USA: evidence for middle Mesoproterozoic sediment-hosted $\mathrm{Co}-\mathrm{Cu}$ sulphide mineralisation with Grenvillian and Cretaceous remobilization. Ore Geol Rev 86:509-525
Scharrer M, Kreissl S, Markl G (2019) The mineralogical variability of hydrothermal native element-arsenide (five-element) associations and the role of physicochemical and kinetic factors concerning sulfur and arsenic. Ore Geol Rev 113:103025

Shirey SB, Walker RJ (1995) Carius tube digestion for low-blank rhenium-osmium analysis. Anal Chem 67:2136-2141

Smoliar MI, Walker RJ, Morgan JW (1996) Re-Os ages of group IIA, IIIA, IVA, and IVB iron meteorites. Science 271:1099-1102

Spišiak J, Vetráková L, Chew D, Ferenc Š, Mikuš T, Šimonová V, Bačík P (2018) Petrology and dating of the Permian lamprophyres from the Malá Fatra Mts. (Western Carpathians, Slovakia). Geol Carpath 69:453-466

Varček C (1978) Theoretical aspects of the ore prognosis in the Tatroveporic complexes. Dep. of Ore Geology, Charles Univ. Prague, $81-85$

Vermeesch P (2018) IsoplotR: a free and open toolbox for geochronology. Geosci Front 9:1479-1493

Völkening J, Walczyk T, Heumann K (1991) Osmium isotopic ratio determinations by negative thermal ionization mass spectrometry. Int J Mass Spectrom Ion Phys 105:147-159

Wise SA, Watters RL (2011) Reference Material 8599 Henderson Molybdenite. Nat Inst Stand Technol, Rep Invest

Publisher's note Springer Nature remains neutral with regard to jurisdictional claims in published maps and institutional affiliations. 